\title{
RELAÇÕES EXTERNAS CONGOLESAS NA PRIMEIRA DÉCADA DO SÉCULO XVII, EM TEMPOS DE D. ÁLVARO II: A EMBAIXADA DE D. GARCIA BAPTISTA E D. ANTÓNIO MANUEL
}

\author{
ILÍDIO DO AMARAL ${ }^{1}$
}

\begin{abstract}
Resumo - Apontamentos sobre as relações diplomáticas entre o Congo, Portugal e Espanha e o Vaticano na primeira década do século XVII (1604-1608), em tempos de D. Álvaro II do Congo, de seu nome africano Mpangu-a-Nimi Lukeni lua Mvemba (reinado entre 1587 e 1613), vistas através de alguns exemplos, nomeadamente da embaixada congolesa composta por D. Garcia Baptista, encarregado dos assuntos mais directamente ligados com a administração filipina (D. Filipe II), e D. António Manuel, marquês de Vunta, com destino a Roma, para se avistar com o Papa. Chegados a Portugal no último trimestre de 1605 , depois de uma viagem atribulada, com passagem pelo Brasil, o primeiro entregou um longo memorial que foi submetido à apreciação demorada do Conselho da Índia e do Vice-rei de Portugal; o segundo encontrou as maiores dificuldades para a sua deslocação a Roma, onde chegou bastante doente a 3 de Janeiro de 1608, falecendo a 5, depois de ter transmitido ao Papa Paulo V o essencial da sua missão. Mereceu funerais com grande pompa e enterramento na Basílica de Santa Maria Maior, onde ainda existem o seu túmulo e busto em mármore atribuído à escola de Bernini. Ficou conhecido entre os romanos por Nigrita. D. Garcia Baptista, que não foi a Roma, regressou ao Congo.
\end{abstract}

Palavras-chave: Congo, Portugal-Espanha, Vaticano, século XVII, relações diplomáticas, embaixadas congolesas.

\begin{abstract}
Foreign Congolese Relations in the First Decade of the XVII ${ }^{\mathrm{TH}}$ Century, in the Times of D. Alvaro II: The embassy of D. Garcia Baptista AND D. ANTONIO MANUEL - This article provides an insight into the diplomatic relationship between the Kingdom of Congo, Portugal and Spain and the Vatican in the first decade of the XVII ${ }^{\text {th }}$ century (1604-1608), being king of Congo D. Álvaro II, whose african name was Mpangu-a-Nimi Lukeni lua Mvemba, and reigned from 1587 to 1618. Some notes are given through several examples of congolese embassies, one of them being composed by D. Garcia Baptista, charged of the affairs more closely related to the Philipine administration (D. Filipe II), and D. António Manuel, the marquis of Vunta, whose destination was the Vatican, to meet the Pope. Both arrived in Portugal in the last quarter of 1605, after a long and troubled journey with a halt in Brazil.The first one brought a long memorial that was submitted to a minute appreciation by the Council of India and by the viceroy of Portugal. Later he went back to Congo. The second met with the greatest difficulties on his
\end{abstract}

1 Professor Catedático jubilado da Universidade de Lisboa. Director do Centro de Geografia do Instituto de Investigação Científica Tropical. Membro da Academia das Ciências de Lisboa e da Academia Portuguesa da História. Rua Ricardo Espírito Santo, 7, C/v E - 1200 Lisboa. Tel. (351 1) 3901978 . 
voyage to Rome where he arrived very ill, on January the $3^{\text {rd }} 1608$ and died on the $5^{\text {th }}$, after transmitting to the Pope the essencial of his mission. He was entitled to a magnificent funeral and was buried in the church of Santa Maria Maior, where his tomb still exists as well as a bust in marble attributed to the school of Bernini. He was known among the romans as Nigrita.

Key-words: Congo, Portugal-Spain, Vatican, XVII ${ }^{\text {th }}$ century, diplomatic relations, congolese embassies.

\section{INTRODUÇÃO}

O reinado de D. Álvaro II do Congo, de seu nome africano Mpangu-a-Nimi Lukeni lua Mvemba, decorrido entre 1587 e 1613, coincidindo parcialmente com os de D. Filipe I e D. Filipe II, foi fértil em embaixadas a estes monarcas e também a Sumos Pontífices. Escolhemos, para este artigo, alguns exemplos das que tiveram lugar entre 1604 e 1608, mormente a de D. Garcia Baptista e de D. António Manuel, pela sua excepcional importância. Utilizamos documentos reproduzidos por António Brásio em volumes da sua Monumenta Missionaria Africana, nomeadamente no V e XV, um artigo nosso de 1987 sobre Mbanza Kongo e algumas partes de livro de 1996 sobre o reino do Congo.

Antes daquela embaixada, temos notícia de uma outra, através de uma nota para o «Bispo Vice-rei», datada de Valladolid, 17 de de Agosto de 1604, em que aparece uma ordem de pagamento a favor de um «embaixador d'el rei de Congo» que tinha estado à espera de resposta a um memorial que apresentara e ainda havia de aguardar em Lisboa «algum tempo» até que houvesse «embarcação» para regressar ao reino africano.

O embaixador solicitara «a mesma ordinária, de cem cruzados cada mês», que recebia na corte espanhola, mas D. Filipe II mandava dar-lhe, desde o dia que chegasse a Lisboa, apenas «cinquenta cruzados por mês, até fim de Outubro» de 1604, «e não mais, por ser o tempo em que haverá embarcação para aquelas partes».

Noutro caso o emissário, um «presbítero» de nome Diogo Gonçalves Manuel, foi acusado pelo colector Francisco de Campos de ter cometido faltas muito graves, como se pode ler, por exemplo, numa carta assinada pelo Secretário Cristóvão Soares para o Cardeal Alberto, Vice-rei de Portugal, datada de 23 de Março de 1605. Em consequência disso, além de ter sido «suspenso do exercício» de sacerdote, recebera ordem de desterro.

Pouco depois incorreria em maior punição, com prisão, por ter desobedecido àquela sentença. Não cumprira a ordem de desterro e celebrara missa publicamente. Proibido de regressar ao Congo, pelos «inconvenientes» que se poderiam «seguir de ele tornar àquelas partes», por uma nota de 30 de Julho do 
mesmo ano ficamos a saber que cumpria a pena «na cadeia, passando misérias e necessidades, por se lhe não dar com que se pudesse sustentar».

Em carta régia para o Vice-rei de Portugal, datada de 31 do mesmo mês, punha-se em dúvida a missão de Diogo Gonçalves Manuel, «que se dizia ser de el-rei de Congo» embaixador, e era ordenado que fossem recolhidos todos os despachos que lhe tinham sido dados e que o seu nome fosse riscado dos registos reais. Mais se determinava que, em caso de revisão do processo, vistas «as culpas da primeira sentença», talvez pudesse «chegar a ser condenado a galés».

Entretanto o Conselho da Índia, encarregado de preparar cartas para o rei do Congo «sobre as culpas» achadas «a Diogo Gonçalves», emitiria o parecer que, de futuro, o monarca congolês poderia «mandar sua procuração aos religiosos de Nossa Senhora da Luz para tratarem de seus negócios, e escusar de enviar seu embaixador».

A D. Filipe II não agradou muito esta forma, como se pode ver na carta para o Vice-rei de Portugal, assinada por Cristóvão Soares, com data de 30 de Setembro de 1605: «é muito contra minha tenção, por não ser conveniente impedir-se os reis enviarem seus embaixadores, antes se ter entendido que de sua residência» na corte resultava «conservar-se melhor a amizade e boa correspondência com eles, e outros efeitos de muita consideração». Por isso mesmo o Rei não assinara as cartas e pedia ao Vice-rei que lhe desse a conhecer «o fundamento que para isso teve o Conselho».

O que parecia ser, à primeira vista, um processo relativamente simples de inculpação de um sacerdote por crimes graves - ainda que não tenhamos encontrado a sua especificação - reveste-se de maior complexidade quando, para além da dúvida levantada por D. Filipe II, tomamos conhecimento do teor de um «ordinário de 10 de Setembro», anterior àquela carta régia, em que o Vice-rei mandava ao Rei um documento favorável ao inculpado, e sugeria que o clérigo pudesse residir em Lisboa ou em Évora, «porque em qualquer delas» acharia «socorro».

Em carta de 31 de Janeiro de 1606 D. Filipe II, reafirmando que vira a carta para o rei do Congo preparada pelo Conselho da Índia, «sobre os embaixadores e os fundamentos que para isso teve», insistia em que não se podia impedir ao soberano congolês o envio de embaixadores. E, sem pôr de parte as opiniões daquele Conselho, concluía do seguinte modo: «hei por bem que a dita carta se torne a fazer, de maneira que fique em sua eleição enviar embaixadores, ou procuração sobre seus negócios aos religiosos de Nossa Senhora da Luz».

Quanto ao presbítero, tão mal tratado, voltamos a ter notícias dele em documento datável de 1606, feito em Roma. Dizendo-se enviado pelo rei do Congo, solicitava ao Papa uma ajuda para o seu sustento enquanto vivesse na Cúria romana, onde chegara «roubado e espoliado de quanto tinha».

Adivinha-se em todo esse processo, que tinha o Congo no centro, a densa trama de interesses políticos e económicos, quer em Mbanza Kongo e Luanda, quer em Madrid e em Lisboa, numa época de intensas relações diplomáticas, que ainda não mereceram estudos de pormenor dos historiadores. 
Neste artigo, como anunciámos, ocupar-nos-emos sobretudo da embaixada que teve o maior relevo e repercussões importantes. Compunham-na D. Garcia Baptista, encarregado de tratar de assuntos mais directamente dependentes da coroa de Espanha e Portugal, a cujo Rei apresentaria um longo memorial, e D. António Manuel, «marquês de Funta» ou Vunta (por vezes com a grafia de Nvunda), seu primo, «homem de cerca de 33 anos, negro, com pouca barba, mas de comportamento nobre e grave, e sobretudo pio e devoto», que «falava em língua portuguesa e castelhana bastante bem», para ir a Roma transmitir ao Papa a situação do Congo, tido como membro da grande família cristã.

Sublinhamos este brevíssimo retrato do embaixador, um homem novo que falava duas línguas estrangeiras, certamente educado por missionários residentes no Congo, porque a cada passo da história congolesa, após as primeiras presenças portuguesas em finais do século $\mathrm{XV}$, se encontram pessoas educadas à europeia, umas no reino africano, mas muitas em Portugal.

Recordemos que o primeiro cardeal negro foi D. Henrique, filho de D. Afonso I, que reinou entre 1509 e 1540 . Estudante em Lisboa durante cerca de dez anos, no Convento de Santo Elói, por cédula consistorial de 5 de Maio de 1518 seria eleito bispo de Útica, tinha apenas 23 ou 24 anos de idade. Regressado ao Congo em 1526, aí exerceu o ministério como vigário do bispo do Funchal. Terá falecido antes de Novembro de 1531.

D. António Manuel, além de instruções datadas de 29 de Junho de 1604, escritas em italiano por um D. Giovanni Battista, na qualidade de secretário do rei, recebeu recomendações orais (trattate a bocca) sobre certos assuntos particulares que devia apresentar ao Papa. O mesmo secretário redigiria, a mandado do seu Rei, uma carta com data de 13 de Julho, pela qual este anunciava ao Santíssimo Padre o envio dos embaixadores. Na altura ainda ocupava a cadeira papal Clemente VIII, que criou a diocese de São Salvador do Congo.

É interessante notar que D. Álvaro II continuava a intitular-se rei do «Congo, Angola, Matamba, Ocanga, Senhor dos Ambundos», etc., cerca de dezanove anos depois da chegada de Paulo Dias de Novais à ilha de Luanda, investido no cargo de capitão e governador, com carta donataria de 19 de Setembro de 1571 que lhe dava amplos poderes para a conquista do «reino de Angola» em favor da coroa portuguesa.

Com a morte de Paulo Dias de Novais em Massangano, a 9 de Maio de 1589, caducara o regime de donataria e Angola tinha passado ao de governo-geral. Luís Serrão e António Ferreira Pereira asseguraram a transição para o primeiro governador-geral de nomeação régia, D. Francisco de Almeida, e a este, até 1604, seguiram-se outros quatro: seu irmão D. Jerónimo de Almeida, João Furtado de Mendonça, João Rodrigues Coutinho e Manuel Cerveira Pereira.

Depois de uma viagem atribulada, com ataques de corsários holandeses e passagem pelo Brasil, os dois embaixadores anteriormente mencionados chegaram a Portugal no último trimestre de 1605 , como permite concluir o texto de uma carta do Vice-rei de Portugal a D. Filipe II, datada de 22 de Novembro daquele ano: 
«hoje entraram nesta cidade os embaixadores d'el rei de Congo, que estavam na do Porto».

E pedia instruções sobre a forma de proceder com eles, «assim no que toca ao tratamento que se lhes há-de fazer, como ao agasalhado que se lhes houver de dar». Ainda não os tinha recebido e, por isso mesmo, nada sabia de concreto sobre as suas missões, mas era de crêr que fossem de «qualidade». Na mesma altura os dois embaixadores escreviam uma carta a D. Filipe II.

A resposta ao Vice-rei, com data de 14 de Fevereiro do ano seguinte, foi de que o tratamento fosse o mesmo que era dispensado a outros embaixadores e que se lhes atribuissem «dez cruzados cada dia, para despesa de aposento, mantimentos e outras coisas necessárias», pagos «pontualmente, do dinheiro que mais pronto» houvesse. D. Filipe determinava ainda que os negócios dessa embaixada fossem vistos com a maior brevidade pelo Conselho da Îndia e pelo Vice-rei, dos quais ficava a aguardar os respectivos relatórios.

Cerca de um mês depois, mais justamente a 18 de Março, o Vice-rei lamentava o facto de não haver verba disponível para as despesas com os embaixadores, «nem para outra alguma», e pedia que o Rei mandasse suprir a Fazenda com os fundos necessários.

Em Maio a questão do provimento de verbas ainda não estava resolvida, como mostra uma carta régia de 13 desse mês, e assim se manteve, pelo menos parcialmente, até finais de Maio de 1607, porquanto a 28 o rei escrevia ao Vice-rei dando-lhe conta de que os embaixadores tinham feito uma petição, em que pediam o «pagamento do que se lhes ficou devendo» em Lisboa, «dos dez cruzados» que lhes fora mandado «dar cada dia». Por isso o Rei pedia que fosse pago «o que constar que se lhes deve do dito mantimento».

Os pormenores têm interesse para relevar as vicissitudes desta embaixada que foi, sem dúvida alguma, a de maior importância até ao primeiro quartel do século XVII. Pena é que ela ainda não tenha merecido a devida atenção dos historiadores e a procura de mais documentação nos arquivos nacionais, espanhóis e do Vaticano.

Ainda de Lisboa, D. António Manuel escreveu ao Papa, para the dar conta da sua missão, e o Sumo Pontífice, que já era Paulo V, em carta de 9 de Dezembro de 1606, responder-lhe-ia em termos muito carinhosos, dizendo que estava ansioso pela sua chegada a Roma.

Depois de algum tempo retido na corte espanhola, a 8 de Julho de 1607 D. António Manuel e a sua comitiva (reduzida a dois ou três congoleses, dos trinta que trouxera do Congo) tomavam o caminho para aquela cidade, acompanhados pelo cardeal João Garcia Mellini, ou Mellino (antigo Núncio em Madrid, de 1605 a 1607), com passagem por Génova e Livorno. A 2 de Janeiro do ano seguinte chegavam, finalmente, a Civittá Vechia e a 3 a Roma.

$\mathrm{O}$ embaixador congolês, que se encontrava então demasiado doente (gravissimamente ammalato di febre, e di altre indispositioni), por instruções de Paulo V foi recebido em Civittá Vechia com muitas honras e carinho por oficiais do seu sobrinho e Secretário de Estado cardeal Scipião Borghese, conduzido a 
Roma em «carroça de campanha e andas», para viajar com comodidade, e bem instalado em aposentos especialmente preparados no Vaticano.

Ao proceder deste modo, o Papa quiz mostrar, certamente, que «tinha em grande consideração» o facto de «um rei, tão remoto e novo» na «santa fé», ter enviado um embaixador para lhe «dar a obediência», o que constituia um bom exemplo para que «outros príncipes e províncias mais próximos» fizessem o mesmo. Sua Santidade visitou-o demoradamente e escutou os pedidos que ele trazia do seu rei, o qual estava desejoso de ver aumentada a cristianização do reino, estabelecidas relações directas com a Santa Sé e diminuída a dependência relativamente à coroa luso-espanhola.

Infelizmente D. António Manuel, que os romanos apelidaram de «Nigrita», faleceria na noite de 5 de Janeiro de 1608, véspera do dia de Reis, depois de receber o santíssimo sacramento e a extrema unção. O Papa fê-lo enterrar, com a pompa que era costume fazer-se aos embaixadores régios, na capela de Xisto V, da Basílica de Santa Maria Maior.

A 12 e 13 de Outubro Sua Santidade escrevia aos nobres do Congo e ao próprio Rei, in Christo fili noster, para lhes dar notícias da morte repentina de D. António Manuel e das homenagens prestadas, e para lamentar o facto de não ter podido ouvi-lo mais longamente, para poder dar satisfação plena aos assuntos da sua embaixada.

Em 1639 os restos mortais do embaixador congolês seriam trasladados para um rico mausoléu construído à entrada do coro da mesma basílica, com um busto de pórfiro negro de fino talhe, que tem sido atribuído a escultor da escola de Bernini.

Tudo isto revela a indiscutível consideração dada pela Santa Sé à embaixada e, sobretudo, a posição importante ganha pelo reino do Congo junto do papado, depois de diversas tentativas infrutíferas, por dificuldades interpostas pela coroa portuguesa.

III

As pretensões apresentadas ao rei de Espanha e Portugal eram muito significativas. Ganham maior relevo quando lidas comparativamente com os pareceres preparados pelo Conselho da Índia sobre os pontos mais importantes do documento entregue por D. Garcia Baptista, tendo ainda em conta as opiniões do Vice-rei de Portugal, os despachos de D. Filipe, geralmente de concordância, feitos nas margens do documento, uma carta régia assinada por João Brandão Soares, datada de 12 de Junho daquele ano, com as respostas mais adequadas e instruções para que tudo se fizesse no sentido de D. Garcia Baptista «embarcar com a maior brevidade que poder ser» e cessassem assim «os inconvenientes que a dilação» podia causar, e outros documentos posteriores.

O primeiro é um documento longo, do qual julgamos do maior interesse reproduzir as partes mais importantes do seu conteúdo. Nas entrelinhas adivinham-se, por um lado, as dificuldades criadas pela existência de dois modos de administração, a congolesa, mais condicionada à sua área de acção, e a portuguesa, com maior preponderância e que marcava as relações com o exterior; e, por outro 
lado, o desejo do soberano congolês de se libertar da dependência em que se encontrava relativamente ao governo de Lisboa-Madrid.

Mui diplomaticamente os membros do Conselho da Índia referiam-se a D. Álvaro II como «um dos maiores reis da Costa de Guiné, cristão, cujo pai e avó» também tinham sido, para acrescentarem prudentemente que, «posto que direitamente não é vassalo de V. Magestade, está todavia debaixo de sua real protecção e obediência».

A afirmação contida na primeira parte desta frase contraditava, de certo modo, antigas pretensões portuguesas, formuladas com base numa provisão que teria sido passada por D. Álvaro I (reinante entre 1568 e 1587), em agradecimento de D. Sebastião o ter mandado libertar do flagelo da invasão dos jagas por volta de 1568. Contudo, não obstante afirmações de diversas pessoas sobre a existência de tal documento, ele nunca foi encontrado.

Ao pedido do rei do Congo para que fossem enviados «religiosos para ajudarem a cultivar a cristandade no seu reino», o Conselho foi de parecer positivo em relação a seis da ordem de São Domingos, na condição do soberano congolês lhes garantir «sustentação» e mandar fazer um mosteiro. Quanto ao pedido de carmelitas descalços, seria melhor aguardar outra oportunidade, até saber-se como os primeiros seriam tratados. Na margem do documento D. Filipe II rubricou a sua concordância.

É curioso que o parecer contrariava a sugestão do embaixador do rei do Congo, em memorial datado de 21 de Março de 1607, onde a preferência era dada aos «carmelitas descalços, que já lá estiveram e edificaram muito»e não aos dominicanos.

Mais curioso ainda o facto do Papa, por carta dirigida ao padre Diogo da Encarnação, a 2 de Dezembro desse ano, ter manifestado o seu desejo de que se pusesse em prática a missão dos carmelitas ao reino do Congo, proposta por frei Pedro da Madre de Deus.

Havia, nitidamente, um jogo de interesses, nos quais nem o próprio Papa queria interferir. E acabou por aceitar a ida dos dominicanos, como se pode concluir de uma carta de D. José de Melo, «agente em Roma dos negócios da Coroa de Portugal», de 30 de Abril de 1608, e de outras missivas de conteúdos idênticos. Dava conta ao Rei de como agira diplomaticamente junto do cardeal João Garcia Mellino para que este comunicasse a Sua Santidade quanto não convinha «mandar àquelas partes frades castelhanos e de outras nações, carmelitas descalços». Por isso mesmo, a preferência dada aos frades de São Domingos.

Sobre a viagem de D. António Manuel a Roma, para «dar obediência ao Santo Padre», o parecer do Conselho da Índia foi no sentido de que lhe poderia ser entregue uma carta de recomendação para o representante da Coroa na Santa Sé. E uma vez que «os reis do Congo» já tinham enviado, noutras ocasiões, «seus embaixadores a Roma, com petições importantes, e algumas queixas», se deveria recomendar àquele representante que ficasse atento ao que o embaixador congolês ia requerer, que procurasse ver as suas petições e que informasse o Papa e seus ministros do que lhe parecesse necessário. 
Tal como no caso anterior, o Vice-rei concordara com essa orientação e acrescentara que o «dito embaixador» não deveria «dar a Sua Santidade papéis alguns, de qualquer qualidade» que fosse, sem os mostrar primeiro ao representante do rei de Espanha e Portugal, «para ele os ver e o encaminhar nas matérias de que houver de tratar».

Este ponto do parecer denota uma certa reserva quanto à presença de D. António Manuel na Santa Sé, confirmada pelo que vem a seguir. O Conselho acrescentava que se sugerisse ao embaixador congolês que podia evitar o incómodo da viagem, remetendo os papéis ao representante da Coroa, que trataria de tudo junto de Sua Santidade. D. Filipe II concordou igualmente com a sugestão. Contudo, no texto da resposta definitiva a fórmula usada foi a seguinte: se, «por sua indisposição e outros impedimentos», D. António Manuel não pudesse «passar a Roma», D. Filipe mandaria «escrever a Sua Santidade sobre as pretensões que trazia a seu cargo» e o seu agente no Vaticano apresentá-las-ia ao Papa.

O rei do Congo queixava-se de que o bispo D. frei António de Santo Estêvão não só se intrometia nas coisas do govemo do seu reino, como também o tratava com muita desconsideração. O parecer do Conselho da Índia foi de que D. Filipe II devia ordenar ao bispo que não se intrometesse no governo temporal do Congo; que não se sentasse na «igreja em trono levantado diante» do rei, «senão quando fizer pontificial»; que procedesse com as devidas «cerimónias, como faziam os outros bispos a seu pai»; que, havendo «matéria de pecado», advertisse o rei com bons modos; e que, no caso de ter de «usar censura contra seus ministros», agisse cautelosamente, informando primeiramente o monarca congolês.

O Vice-rei foi do mesmo parecer no que tocava à jurisdição temporal, mas quanto ao procedimento do bispo aconselhava que este fosse ouvido; mas, entretanto, advertido de que devia ter com o rei do Congo «boa correspondência» e tratamento respeitoso. A concordância de D. Filipe II ficou bem expressa nos seguintes termos: «Escreva-se imediatamente ao bispo» para que trate o rei com o respeito que lhe é devido; e que nas coisas sagradas imponha a sua autoridade, «pois do contrário poderia resultar deserviço de Deus e grandes inconvenientes, e que avise como o faz». Na resposta definitiva o Rei acrescentava a sua confiança no bispo.

Relativamente ao pedido de D. Álvaro para que passasse para a sua alçada a nomeação das dignidades e conesias da Sé, bem como do mestre escola e do tesoureiro da mesma, e a capacidade de «lançar de seu reino» os capitulares que não cumprissem com as suas obrigações, permanecendo nas mãos do rei de Espanha e Portugal a nomeação do bispo, o Conselho recordou que o rei do Congo já recebera carta pela qual ficara autorizado a nomear os membros do capítulo, os quais seriam depois confirmados pelo rei de Espanha e Portugal, que continuava a pagar «as porções que cada um» tinha de receber.

No caso de lhe ser concedida a petição, e uma vez que havia no Congo «clérigos para os tais benefícios», então que o respectivo rei passasse a indicá-los ao bispo, para este «os examinar, aprovar e confirmar», e também a pagar aquelas «porções». No que tocava «ao lançar do reino os que procederam mal», o Conselho 
foi do parecer que isso pertencia ao bispo. O Vice-rei esteve de acordo com tudo e o Rei aprovou inteiramente.

Vemos mais tarde que, por falecimento de Simão Rodrigues Rangel, pregador da Sé do Congo, seria nomeado, por alvará régio de 21 de Junho de 1608, o padre mestre António Pereira, com o ordenado de cem mil réis por ano, retirados «dos direitos de escravos do reino de Angola, a vencer do dia» em que tomasse posse do cargo, «dada pelo Bispo do dito reino», ou por quem o substituísse.

O primeiro tesoureiro e o primeiro mestre-escola da Sé do Congo, respectivamente, Manuel Correia, «sacerdote canonista» e João da Estrada, «sacerdote, capelão e teólogo aprovado», seriam nomeados por cartas régias de 9 de Fevereiro de 1610, na altura em que já era bispo de Congo e Angola D. frei Manuel Baptista, franciscano da Província da Observância dos Algarves, eleito no ano anterior.

Quanto ao desejo do rei do Congo para que não houvesse alterações do modo de arrecadação dos dízimos, até aí cobrados por «oficiais seus tesoureiros (os manibampas ou manibambas)» que posteriormente os entregavam aos priostes (antigos cobradores de rendas eclesiásticas) para os dividir pelos eclesiásticos, o Conselho foi de opinião que se mantivesse o que já estava concedido, o que contrariava a intenção do bispo, que os queria «arrecadar de sua mão».

Argumentava o Conselho que, «por ser esta cristandade nova e tenra na fé, em costumes eclesiásticos», não se devia inovar «coisa alguma do costume antigo». O Rei aprovou também este parecer, uma vez ouvido, como nos outros casos, o Vice-rei.

Ao pedido de «alguns ornamentos para a Sé, imagens de santos, um sacrário para o Santíssimo Sacramento, alguns sinos grandes, uns órgãos, livros para as missas e oficios divinos, e algumas relíquias de santos», os conselheiros recomendaram que fossem enviados «um ornamento pontificial de damasco branco com sanastros de tela, de pouco custo», que tivesse «lustre, e aparência», e outro «vermelho, do mesmo, e duas imagens de vultos, uma de Nossa Senhora, e outra de São Miguel, um sacrário de madeira, dourado, uns órgãos pequenos, alguns livros para a igreja, porque assim o costumaram fazer sempre os reis de Portugal», e ainda «uma imagem de Cristo, de vulto, e um retábulo dos Reis Magos».

Mais acrescentava que, por via da Junta da Fazenda, fosse provido «o dinheiro necessário para em Lisboa fazer-se tudo isso, com a brevidade» possível. O Rei despachou com a recomendação de que «estes ornamentos e imagens, e o demais», fossem «enviados cumpridamente». Mais do que isso, em carta de 4 de Maio de 1607 mandava entregar ao embaixador D. Garcia Baptista os «ornamentos, imagens e mais coisas», para cuja aquisição deveria ser utilizado «qualquer dinheiro que mais pronto» houvesse, ainda que estivesse «aplicado ou consignado a outras obrigações», ainda que fosse necessário pedir emprestado, pois se tratava de «serviço de Deus» e Seu «enviar-se àquele reino» tais objectos de culto.

Se até aqui os conselheiros e o Vice-rei se manifestaram favoráveis aos pedidos do rei do Congo, um mereceria parecer desfavorável - o de «alguns mestres pedreiros e ferreiros para lá fazerem obras». Em tom muito categórico, e algo surpreendente, afirmavam que «se lhe não devem enviar oficiais, nem convém que tenha em seu reino quem saiba fazer obras de pedra e cal, nem de ferraria, porque não 
seja ocasião de alguma desobediência». E se os embaixadores congoleses os quizessem levar que fossem estorvados «por bom meio, sem escândalo». Teve o seguinte despacho do rei: «está bem».

O rei do Congo solicitara o envio de «um capitão» para a «gente branca» que vivia no seu reino, para aí residir «de contínuo», provido de três em três anos, com instruções de como deveria proceder dentro de limites adequados. O Conselho, ainda que lhe parecesse que havia «alguns inconvenientes» na concessão de tal pedido, e que a melhor solução seria a de «não se consentir em seu reino portugueses, para que não» ensinassem «aos naturais dele a milícia e usar das armas, e outras coisas de pouco serviço» do rei de Espanha e Portugal, ponderava em que, sendo «mui dificultosa tirá-los» (os portugueses) «do dito reino», pois «disso se seguiria escândalo», ao fim e ao cabo seria melhor ter toda essa gente «debaixo da obediência de um capitão português», com «instrução secreta (além da pública) de algumas coisas que parecer se não devem exprimir no regimento».

Em relação com este ponto, achamos curioso que no memorial do embaixador congolês, datado de 21 de Março de 1607, fosse citado um nome que, pelos vistos, merecia inteira confiança ao rei do Congo: o de D. Jerónimo de Almeida, «que já estivera por governador em Angola», num curto período, de 1593-1594, porque como homem que sabia «dessas partes» poderia servir bem os dois reis e poderia fazer muito pelas minas descobertas no Congo! Não sendo possível nomeá-lo, então que fosse «um fidalgo castelhano», que fizesse «sempre verdadeira informação de tudo». Os outros governadores de Angola eram acusados de usarem «grandes insolências contra» o seu soberano, «soltando palavras não decentes a um rei católico, irmão» do rei de Espanha e Portugal.

Queixava-se o embaixador da demora de resposta aos apontamentos que entregara ao Conselho da Índia, pelo facto de já estar há «dois anos fora» da sua terra «e roubado de holandeses» - referência aos ataques dos corsários na viagem do Congo para Portugal -, e há «seis meses» na corte castelhana, «com grandes necessidades, deixando em Lisboa dívidas de mercadores» que lhe tinham emprestado «dinheiro e fazenda», sem saber como pagar.

No parecer do Conselho da Î́ndia sugeria-se que fosse construído, «em algum sítio mais conveniente da cidade de Salvador», isto é, de Mbanza Kongo, «uma fortaleza, ou cerca», dentro da qual viveriam o capitão, «os portugueses com suas mulheres» e onde se recolheriam também os tangomaos. Ela serviria, igualmente, para alojar «o dito rei e os seus mais obedientes».

Abrimos aqui um parênteses para recordar que já em tempos de D. Afonso I, de seu nome africano Mvemba-a-Nzinga, de acordo com a Relação do reino de Congo, de Duarte Lopes e Filippo Pigafetta, este rei mandara cingir «a cidade de muralhas, dando aos portugueses separadamente o seu lugar, vedado com muros, e ele cercando também o seu palácio e as casas reais com muros, e deixando no meio destes dois serralhos um grande espaço, onde foi fabricada a Igreja principal com seu terreiro defronte; e as portas, assim das casas solariegas como das habitações dos portugueses, olham para o lado da sobredita igreja; e no principio do terreiro moram alguns Senhores, Grandes da Corte; e nas traseiras da igreja o terreiro acaba numa rua estreita, que tem sua porta, passada a qual há muito casario da banda do 
levante. Fora destas muralhas, em que estão contidos os passos reais e a cidade dos portugueses, muitas outras casas se topam de Senhores diversos: cada um tomando desordenadamente o sítio que lhe parece bem, para residir junto à Corte». Entretanto decorrera quase um século e tinha havido muitas alterações.

Retomando o parecer do Conselho da Índia, o capitão devia ser pessoa de confiança de D. Filipe, nomeada e paga por Sua Magestade, sem qualquer dependência do rei do Congo, para exercer o cargo com a maior isenção. Nesta matéria parece que não concordou inteiramente o Vice-rei. $\mathrm{O}$ assunto seria retomado num documento do Conselho, de 7 de Novembro de 1607, comunicando que, de quatro pessoas propostas - António Gonçalves Pita, Jorge Borralho, João Travaços da Costa e Francisco Vaz de Medeiros, todos eles «fidalgos da casa» real e cavaleiros do hábito de Cristo -, o Vice-rei escolhera o primeiro.

O Conselho considerava que três anos constituiam um período demasiado curto para interessar «pessoa de qualidade, serviços e experiência» e alvitrava cinco anos; que se devia «nomear ordenado certo» e indicava «pelo menos trezentos mil réis» por ano, pagos pelo rei do Congo, contrariamente ao seu anterior parecer.

O documento de nomeação, feito em 11 de Dezembro, de acordo com essas indicações, viria a ter alterações posteriores. Assim, por cartas régias de $10 \mathrm{de}$ Junho e de 29 de Setembro de 1608, o ordenado de António Gonçalves Pita «e dos mais oficiais» pagar-se-ia por conta da Fazenda real e «não de el-rei de Congo», como fora determinado; a designação seria a de «capitão mor da gente portuguesa» do Congo, «subordinado ao capitão geral e governador d'Angola». Além disso, era deferido o pedido do nomeado para que a comenda que tinha, por sua morte, ficasse «a um seu filho ou para pessoa» que casasse «com sua filha», desde que tivesse servido no Congo o tempo estipulado, «e com satisfação»; e ficava autorizado a levar «duas dúzias de arcabuzes por empréstimo, obrigando-se a dar conta deles, depois de acabar de servir», e dois homens da sua confiança, «por moços da Câmara».

Decorreriam cerca de quatro meses até ser passada, a 10 de Janeiro de 1609, a carta de patente de capitão mor de «todos os portugueses e vassalos de qualquer qualidade e condição, que ao presente» residissem ou viessem a residir ou a estar «por qualquer via no reino e senhorios do Congo». O capitão recebia autoridade para os governar «em todas as coisas de paz e guerra», segundo o disposto nas leis e ordenações portuguesas e nas instruções do seu regimento, um documento que ainda se desconhece.

Entretanto, o nomeado retardava a partida para o Congo, procurando obter mais mercês. Sirva de exemplo a de provedor da fazenda dos defuntos e ausentes do Congo, que lhe foi concedida por carta de 11 de Março, desde o momento em que acabasse o tempo da pessoa que ora servia em tal cargo; teria o ordenado fixado no regimento dos defuntos da Guiné e do Brasil. A 30 de Junho o rei mandava que ele embarcasse «logo, a servir o cargo».

A 20 de Agosto ainda lhe era dada autorização para que tivesse, enquanto capitão mor, uma força de seis homens, cada um deles com um ordenado de vinte mil reis por ano, pagos pelo feitor ou almoxarife da Fazenda real em Angola. Tais ho- 
mens teriam de ter entre vinte e cinquenta anos de idade; falecendo algum deles, o capitão poderia substituí-lo por outro.

Cinco dias depois insistia-se na partida do capitão. Sem termos tido a preocupação de saber muito mais sobre o assunto e também acerca das suas actividades no Congo, limitamo-nos a acrescentar que, num curto período de 1617, desempenhou o cargo de governador de Angola, entre o segundo mandato de Manuel Cerveira Pereira e o de Luís Mendes de Vasconcelos, quando o Congo já tinha por rei D. Álvaro III, depois de um curto reinado de D. Bernardo II.

Também não houve concordância de opiniões dos membros do Conselho da Índia quanto ao pedido de serem enviados, «de Portugal, homens brancos com suas mulheres para viverem» no Congo «e donzelas para se casarem lá, para com isso se dilatar a fé». Segundo aquele Conselho, a única resposta era a do indeferimento, «por ser mui prejudicial ter aquele rei vassalos brancos», porque com eles se faria «tão poderoso» que procuraria «eximir-se da obediência»a D. Filipe.

O Vice-rei, porém, deu um parecer mais maleável: negando-se oficialmente o envio de homens brancos, todavia, se houvesse quem quizesse ir, não devia ser impedido de o fazer. Tal parecer acabou por ser adoptado pelos conselheiros.

D. Álvaro II solicitara «alguns favores e honras» para pessoas «da Câmara de sua cidade, assim portugueses, como naturais da terra, pelo trabalho no bem público, e em sustentar muitas confrarias». Os pareceres do Conselho e do Vice-rei foram no sentido do indeferimento, porquanto não se sabia que favores e honras eram esses. No entanto, sobre tais matérias, poderiam ser ouvidos o bispo e o capitão. Outro pedido era em favor dos seus capelães, para os quais desejava os privilégios e liberdades que gozavam os do rei de Espanha e Portugal. Os pareceres concordaram em que isso fosse concedido, por não haver «inconveniente».

Havia também a solicitação de afidalgamento de Diogo Roiz Pestana, que fora seu capelão mor e confessor, e que na altura já o era de D. Filipe. O Conselho e o Vice-rei, tendo verificado, por certidões apresentadas, que o «dito Diogo Roiz» era «nobre da parte de seu pai», deram pareceres favoráveis. Também o fizeram em relação aos portugueses Custódio de Barros e André Pimenta Raposo, pelos bons serviços prestados como capitão e sargento mor no reino do Congo, e ao congolês Cosmo Álvares, capelão e secretário da embaixada, «pelo zelo» posto no «serviço de Deus e aumento da cristandade».

Menos pacificamente foi vista a pretensão do rei do Congo para que D. Filipe confirmasse «alguns hábitos» que ele concedera a «fidalgos seus, por muitos serviços» que lhe tinham prestado nas guerras «contra seus tios e irmãos». O Conselho recordava que tal petição já fora feita em tempos anteriores e que a resposta fora negativa: o rei do Congo não podia conceder hábitos de ordens militares, «nem se devia intrometer em matérias semelhantes, por dependerem de bulas e privilégios dos papas».

Atendendo ao facto do Vice-rei aconselhar que devia ser dada «alguma escusa de se lhe não conceder» o que pedia, «com que ele se satisfaça», o Conselho dividiu o parecer em duas partes. Por um lado, em tal matéria não se podia «proceder por termos gerais» e a única resposta era a de fazer saber ao rei do Congo que ele se tinha «excedido muito em dar hábitos, sem ter para isso 
faculdade, nem licença» do rei de Espanha e Portugal, que era, por bulas apostólicas, «administrador perpétuo e governador das ordens militares». Deste modo, D. Filipe devia mandar recolher os hábitos, proibindo que as pessoas a quem tinham sido dados os usassem. Mas, por outro lado, se estivesse na sua vontade conceder alguns, «um hábito de cada uma das três ordens militares de Portugal» (Aviz, Cristo e Santiago), o rei do Congo deveria, primeiramente, indicar as pessoas, escolhidas entre os «de muita qualidade, e parentes seus mais chegados», para que fossem passados «os despachos necessários».

Uma portaria de 21 de Fevereiro de 1609 concederia «um hábito de cada uma das três ordens militares, por uma vez somente». No seguimento de pedido feito pelo embaixador do Congo, dado que o reino africano ficava muito distante, tendo em conta que era «incerta a viagem para ir recado a el-rei» dessa graça e depois vir a nomeação das pessoas, para a qual era preciso contar com o tempo de se fazerem «as inquirições das provanças e mais diligências ordinárias, o capitão geral da gente portuguesa» receberia alvará para fazer essas «provanças» e dispensar «com elas no defeito de gentios se o tiverem, ou em outros quaisquer», para assim poderem receber os hábitos. Estes seriam impostos por «pessoa constituída em dignidade», depois dos nomeados serem armados cavaleiros pelo capitão geral, «na forma dos estatutos» existentes. No caso de se provar que entre os escolhidos os havia «de casta e geração de mouros ou judeus», os processos teriam de ser apresentados ao rei de Espanha e Portugal para decidir sobre eles.

Também não foi pacífica a apreciação do pedido do rei do Congo, que saissem do seu reino «os portugueses cristãos novos» aí residentes, «por serem nocivos em seus tratos» (negócios). O Conselho da Índia recordava que já houvera uma provisão sobre o assunto - proibição de os cristãos novos irem ao reino do Congo -, da qual se podia mandar um treslado ao soberano congolês. Mas por nenhum modo se deveria passar para ele a execução das medidas, «porque isso seria meio de se dar moléstia e vexação aos vassalos» do rei de Espanha e Portugal. Parecer favorável mereceu a solicitação de que «toda a fazenda defesa, que sem registar pelos da sua câmara», passasse «ao resgate daquelas partes», fosse dada como perdida, «a metade para o acusador e a outra metade para obras pias».

As relações com os governadores portugueses de Angola não corriam bem e D. Álvaro queixava-se amiudadas vezes de abusos cometidos por essas autoridades. Na lista de pedidos que temos estado a tratar se incluia o da restituição de terras que «João Furtado de Mendonça, governador de Angola» entre 1594 e 1602 , repartira e dera de sesmaria, «sem ter para isso poder bastante». Um desses actos fora o da doação de terras da ilha de Luanda ao mosteiro de Santa Marta de Lisboa.

O Conselho da Índia deu-se ao cuidado de inquirir o ex-governador, obtendo a resposta de que as terras em que dera as ditas sesmarias pertenciam à Coroa e que a doação constara somente de «licença» ao procurador do mosteiro «para fazer umas choças de palha, junto a um surgidouro, fora da povoação, donde se vêm a embarcar os escravos, de que pagam para as obras do mosteiro alguma coisa, por ser muito pobre». E isso fizera no âmbito dos poderes do regimento que the fora outorgado. Em face dessa explicação, o Conselho emitiu o parecer de que o rei 
devia ordenar ao «governador que ora vai àquelas partes» (tratava-se já de D. Manuel Pereira Forjaz, governador entre 1607 e 1611) que colhesse informações sobre a matéria, para melhor apreciação do assunto. Com isso esteve de acordo o Vice-rei.

D. Álvaro solicitara a prisão e transferência para Portugal de «um Custódio Antunes, residente na vila de São Paulo de Luanda», e que ele mandara «em ferros a João Furtado de Mendonça» para ser castigado, porquanto se conluiara com «um fidalgo seu vassalo» para o matarem. O governador não só não o castigara como o soltara e favorecera. O Conselho, depois de se debruçar sobre o auto de culpa enviado pelo rei do Congo e sobre as informações prestadas por João Furtado de Mendonça, concluiu que não havia matéria bastante «para se proceder contra» aquele homem. No entanto, «para satisfação do dito rei», poder-se-ia «ordenar ao governador» que ia para Angola que fizesse embarcar para o reino o dito Custódio Antunes, para melhor esclarecimento do assunto,

A conquista portuguesa do chamado reino de Angola preocupava o rei do Congo por vários motivos, um dos quais era, certamente, a perda de interesse dos comerciantes portugueses pelas coisas do seu reino, com prejuízos evidentes que o afectavam. Na listagem de assuntos encontra-se um referente às minas de prata e de cobre, que o soberano congolês pretendia ter sobejamente nas suas terras. Recordemos que, em tempos anteriores, os reis do Congo procuraram impedir que os portugueses encontrassem e se ocupassem dessas minas. Mas agora, em face da atração exercida pelas jazidas promissoras de Angola, o próprio rei oferecia as do seu reino para exploração.

Segundo ele, com base em «informação por via de seus vassalos», estava certo de que não havia prata nas minas de Cambambe (Angola); por isso mesmo, o rei de Espanha e Portugal não deveria «fazer mais despesas naquele descobrimento». É interessante verificar que era essa também a opinião dos membros do Conselho da Índia, já anteriormente transmitida a D. Filipe, no sentido de «que se não tratasse mais do dito descobrimento». Na margem deste longo parecer o Rei despachou do seguinte modo: «está bem o resolvido».

D. Álvaro, em contrapartida, acenava com as minas de cobre existentes no Congo, as quais mandara «já oferecer por seu embaixador», e renovava o pedido de «mineiros para as beneficiar». Para o Conselho não valia a pena discutir o assunto porque «no reino de Angola e terras vizinhas» havia notícia de existirem essas «minas, muito copiosas», que se poderiam explorar por conta da Coroa, com muito mais proveito do que aquelas oferecidas pelo rei do Congo. Também o Vice-rei deu preferência às de Angola. Quanto às do Congo, elas poderiam vir a ser utilizadas no caso das primeiras não se revelarem tão abundantes e ricas como se pensava.

Ao pedido de provisão para poder «tirar todos os anos vinte peças de escravos da feitoria de São Tomé, forros, para serviço do culto divino», na forma que o anterior rei concedera a seu pai, o Conselho e o Vice-rei foram do parecer que o rei do Congo apresentasse «treslado da provisão» que fora passada. 
Nas instruções dadas a D. António Manuel, o embaixador destinado a Roma, naquilo que se sabe, aparecem outras queixas e solicitações do rei do Congo. Infelizmente, porém, não se conhece na íntegra o documento de que terá sido portador. Apenas há o registo parcial do que terá comunicado ao Papa. Nada é comparável à apreciação minuciosa feita pelo Conselho da Índia e pelo Vice-rei de Portugal do texto entregue por D. Garcia Baptista,

D. Álvaro II pedia que Sua Santidade o tivesse como seu feudatário, para o defender contra as afrontas que lhe faziam os prelados; que lhe concedesse graças e privilégios semelhantes aos que eram dados aos demais reis e príncipes cristãos. Em contrapartida, oferecia à câmara apostólica «certa porção» dos metais que se descobrissem no seu reino.

Mais pedia que o Papa condenasse aqueles que pilhavam não só essas riquezas, mas também a moeda mais corrente no Congo, isto é, o zimbo, particularmente o recolhido na ilha de Luanda, por ser considerado o mais valioso, pois com isso empobreciam o reino.

Mostrava-se muito desagradado com o bispo, a quem acusava de várias coisas: de se dedicar ao jogo, utilizando parte dos dízimos; de obrigar os meninos de 14 anos a jurarem em falso, sob pena de excomunhão; de ser pouco rigoroso nas condenações; de ter pouco respeito pelos capitulares, mandando-os encarcerar por tudo e por nada; de não respeitar os privilégios do Concílio tridentino.

Queixava-se do cabido da Sé e acusava os seu membros de forjarem processos falsos para o difamarem junto do rei de Espanha e Portugal e do Sumo Pontifice, e de, com o mesmo fim, conspirarem com as autoridades portuguesas de Luanda. Por isso mesmo solicitava ao Papa que enviasse um sacerdote para se informar sobre esses assuntos, mas nunca um português, porque não confiava na isenção de pessoa dessa nacionalidade.

Solicitava licença para poder legitimar um dos seus filhos naturais, uma vez que não tinha filhos legítimos com a rainha, sua mulher. Gostaria de receber relíquias de santos e Agnus dei, para repartir com fidalgos e igrejas, e um breve que isentasse a sua capela de $\mathrm{S}$. Tiago da jurisdição do bispo.

Também pedia um breve para que «os homens e mulheres que tivessem vivido seis ou sete anos» no Congo «pudessem ser tidos como naturais do seu reino, como se fazia nos outros reinos de cristãos».

Dava conta de que libertara os portugueses aprisionados em Matamba «durante 12 ou 14 anos», certamente uma alusão aos resultados da derrota infligida ao governador Luís Serrão, junto do rio Lucala, em 29 de Dezembro de 1589. segundo a «História da residência dos padres da Companhia de Jesus em Angola, e coisas tocantes ao reino, e conquista», datada de 1 de Maio de 1594, ou «em sexta-feira derradeira oitava de Natal do ano de noventa», conforme consta no relatório de Domingos d'Abreu de Brito, de 1591.

Comunicava que se tinham feito cristãos quatro reis gentílicos, de «Cundi, Cala, Ocanga e Zareacacongo», e que outros poderiam abraçar o cristianismo desde que o Papa concedesse muitos privilégios.

Como referimos anteriormente, D. António Manuel faleceu no Vaticano e a sua presença ficou bem marcada no túmulo e busto existentes na Basílica de Santa 
Maria Maior, em Roma. Quanto ao outro embaixador, tudo leva a crer que tenha regressado a Mbanza Kongo. Não esteve em Roma mas, ainda no início da missão, recebeu uma carta do Papa, de 9 de Dezembro de 1606, consolando-o pelo facto de não ter tido a oportunidade de ir ao Vaticano. Em meados de 1607 havia instruções para que ele fosse despachado com toda a brevidade.

\section{BIBLIOGRAFIA}

Amaral, I. (1987) - Mbanza Kongo, cidade do Congo, ou São Salvador. Contribuição para o conhecimento geográfico de uma aglomeração urbana africana ao sul do Equador, nos séculos XVI e XVII. Garcia de Orta. Série de Geografia, 12 (1-2): 1-40.

AmARAL, I. (1996) - O reino do Congo, os Mbundu (ou Ambundos), o reino dos «Ngola» (ou de Angola) e a presença portuguesa de finais do século XV a meados do século XVI. Ministério da Ciência e da Tecnologia, Instituto de Investigação Científica Tropical, Lisboa. (Prémio de História Calouste Gulbenkian, Presença de Portugal no Mundo, da Academia Portuguesa da História, 1997).

BRÁsio, A. (1955) - Monumenta Missionária Africana: África Ocidental. Vol. V (1600-1610). Agência Geral do Ultramar, Lisboa.

BRÁsIO, A. (1988) - Monumenta Missionária Africana: África Ocidental. Vol. XV (Suplemento séculos XV, XVI e XVII). Academia Portuguesa da História, Lisboa.

BRITO, D. (1591) - Sumário e descrição do reino de Angola e do descobrimento da ilha de Luanda e da grandeza das capitanias do Estado do Brasil. 1591. Texto publicado por A. DE ALBUQUERQUE FELNER (1931) - Um Inquérito à vida administrativa e económica de Angola e do Brasil em fins do século XVI. Imprensa da Universidade, Coimbra, XIX + $97 \mathrm{p}$.

LOPES, D.; F. PIGAFETTA, (1951) - Relação do reino de Congo e das Terras circunvizinhas. Agência Geral do Ultramar, Lisboa. (Tradução de Relatione del Reame di Congo et delle Circonvicine Contrade: 1591, por Rosa CAPEANS). 